\title{
PECULIARITIES OF TUTORING AND MENTORING IMPLEMENTATION AT HIGHER EDUCATIONAL ESTABLISHMENTS OF UKRAINE
}

Summary. The possibilities of tutoring and mentoring implementation at Higher Educational Establishments of Ukraine are analyzed in the article. It is mentioned that higher education reforming demands the implementation of international experience at HEEs. The research proves that tutoring and mentoring at HEE directly influences quality assurance and students success. The issue is very topical nowadays because of academic mobility realization. The article provides best examples of tutoring and mentoring organization at the European HEEs.

Keywords: tutoring, mentoring, internationalization, quality assurance, academic mobility.

Іваницька O.C.

Національний університет «Львівська політехніка»

\section{ОСОБЛИВОСТІ ВПРОВАДЖЕННЯ ТЬЮТОРСТВА ТА МЕНТОРСТВА У ЗАКЛАДАХ ВИЩОЇ ОСВІТИ УКРАЇНИ}

\begin{abstract}
Анотація. В статті проаналізовано можливості впровадження тьюторства та менторства у закладах вищої освіти України. Зазначено, що реформування вищої освіти вимагає застосування міжнародного досвіду у ЗВО. Стаття підтверджуе, що тьюторство та менторство безпосередньо впливае на забезпечення якості у ЗВО та успішність студентів. Тема сьогодні є надзвичайно актуальною в зв’язку з реалізацією академічної мобільності. Стаття включає успішні приклади реалізації тьюторства та менторства в європейських ЗВО.
\end{abstract}

Ключові слова: тьюторство, менторство, інтернаціоналізація, забезпечення якості, академічна мобільність.

The problem setting. The issue of tutoring 1 and mentoring is very topical nowadays in the Ukrainian system of higher education. The need for the tutoring and mentoring implementation is caused by new reforms and quality assurance providing. The lack of information, research as well as higher education projects financing are among the challenges and obstacles in the process of the tutoring and mentoring implementation at HEEs of Ukraine.

The aim of the article is to analyze the current state of tutoring and mentoring at Higher Educational Establishments of Ukraine as well as possibilities for their implementation.

Analysis of recent research and publications. The research of tutoring and mentoring is done by scientists whose articles are based on practical implementation of tutoring and mentoring at HEEs as well as provide recommendations for the tutoring and mentoring development (Nuria Ruiz Morillas, Manel Fandos Garrido, 2014; Guidelines for mentoring and supporting students, 2005). Peer learning is explained as important type of learning for providing students comfort and success (Pisano, Berger, 2016). Foreign scientists pay much attention to the quality assurance in higher education and improvement of teaching methods (Pleschova, Simon, Quinlan, Murphy, Roxa, Szabo, 2012). Ukrainian scholars research the history of tutoring and mentoring and outline best practices of its implementation (Boyko, 2010; Podpliota, 2017). Besides, new research appears on the possibilities of the tutoring and mentoring implementation at HEEs of Ukraine under the current conditions (Demianenko, 2018; Ivanytska, 2018).

Presentation of the main material. Nowadays, higher education not only in Ukraine, but in whole Europe undergoes changes in frames of internationalization policies development and higher education reforming. Therefore, there are several challenges for every University.
Academics in Europe are not as prepared for their teaching careers as they are for their research and changes in higher education make the development of academics' teaching skills one of the most priority issues (Pleschova, Simon, Quinlan, Murphy, Roxa, Szabo, 2012). The problem is caused by several rankings which take into account quantity of scientific papers, participation at conferences but not the teaching professionalism. The situation is typical for many countries, including Ukraine. Now we understand that qualification of teaching staffs and their friendly attitude towards students directly influence on students achievements and make them competitive on the labor market after the university graduation. "Staff involved in teaching and supporting student learning should be qualified, supported and adequately resourced for that role» (Pleschova, Simon, Quinlan, Murphy, Roxa, Szabo, 2012, p. 6).

In relation to this issue, nowadays professionals who are engaged in higher education reforming process understand the necessity to pay more attention to teaching and education process in general. «Teaching is still viewed as an activity that anyone can do, the preparation of university teachers remains largely unsystematic. Europe has established a European Higher Education Area (EHEA) with the purpose of creating comparable, compatible and coherent systems of higher education, increasing the employability of graduates, and enhancing the international competitiveness of European universities. Establishing professional standards for higher education teaching across Europe, the introduction of student-centered teaching, and the preparation of academics to fulfill these requirements are important steps to achieve these aims. So far, European policies have rarely affected the quality of teaching at the class-room level» (Pleschova, Simon, Quinlan, Murphy, Roxa, Szabo, 2012, p. 7). 
Additional assistance is needed to maximize learning and ensure students safety. Mentors especially focus on the students needs, develop their self confidence and provide them with the information on future perspectives (Guidelines for mentoring and supporting students, 2005).

«Tutoring is a part of the university teaching-learning process and is a basic strategy for improving the student's academic success and professional goals. It is also in line with the policies of the European Union for improving the integration of lifelong guidance into lifelong learning strategies» (Nuria Ruiz Morillas, Manel Fandos Garrido, 2014, p. 89).

Tutoring and mentoring successfully operate at European HEEs providing high quality education for their students, including international ones. The countries with the best developed system of tutoring and mentoring are England and Germany. England is famous for the earliest implementation of tutoring and mentoring which dates back to the Medieval Era. Nowadays, all English universities have mediators between students and professors. At most German HEEs there are tutors, students who work with junior students on subjects, home tasks material preparation etc., and mentors, professional staffs who provide psychological and organizational assistance.

Tutoring and mentoring enable students to achieve their professional goals. Such assistance is especially important who have some problems during study process or some misunderstandings with other students because of gender equlity, religious views, and affiliation to different races and cultures (Nuria Ruiz Morillas, Manel Fandos Garrido, 2014).

This aspect should be taken into consideration in the Ukrainian higher education area as more and more international students come to the Ukrainian HEEs in frames of academic mobility programmes, especially Erasmus, for one or two semesters study. Therefore, tutors and mentors are needed to help them in the adaptation period especially during first weeks of study.

The main functions of tutors nowadays include the following: «facilitate the integration of students into university; assist the students in their academic work; help students solve problems related to academic and university life; facilitate the student's personal and professional progress; help the student in his/her transition to the professional world» (Nuria Ruiz Morillas, Manel Fandos Garrido, 2014, p. 94).

One of the most important factor of the tutoring success is the establishment of good relations between students and tutors (Nuria Ruiz Morillas, Manel Fandos Garrido, 2014). Therefore, in Germany, for example, big attention is paid to the qualification of tutors and providing them with the recommendations how to behave during tutorials.

While talking about the types of tutors, peer tutoring is believed to be the most successful at European HEEs as it is easier for the people of the same age to understand each other. Besides, peer tutors are also involved in the educational process, therefore they easier find solutions to common problems.

Peer tutoring is very important as peer learning encompasses a number of different mechanisms or instruments that support learning from and with peers with regard to sustainable development. It means that learning relationship is set between equals, therefore a different form of learning is implied. Peer tutoring foresees sharing of knowledge, ideas as well as experience between the participants of the educational process (Pisano, Berger, 2016). «Peer learning activities result in: a team-building spirit and more supportive relationships; greater psychological well-being, social competence, communication skills and self-esteem; higher achievement and greater productivity in terms of enhanced learning outcomes» (Pisano, Berger, 2016, p. 6).

Changes in higher education of Ukraine during recent years were caused first of all by the Bologna process implementation in higher education. As the Bologna process foresees the increase of attention to students needs and the realization of their possibilities, there is the need for the tutoring and mentoring implementation at every university. In comparison with other countries these are teachers who set educational goals in Ukraine, while in England, for example there is teacher-student tandem in goals setting and their realization (Podpliota, 2017).

Topicality of tutoring is caused by the need to satisfy educational demands of the individual, it visually demonstrates the dependence of country development on the education results of separate individuals etc. The role of tutor in higher education is to attract students to different types of individual work including project, research, organizational ones, which promote critical understanding of their achievements, unsolved problems, constant challenges of their individual activity, it's reflection, formulation of their own tasks as well as correction of their activities. There are benefits when students may perform duties of tutors as they are approximately the same age, common interests and perception of life. There is the urgent need for tutoring implementation nowadays for the organization of individual students work. Unfortunately, there is no enough attention to individual work at higher education (Boyko, 2010).

The above mentioned information shows the interest increase to the tutoring and mentoring in higher education of Ukraine. It is also caused by a large number of students who participate at international programmes or projects and demand more supervising.

Society supports the modernization of higher education, including lifelong learning and distant learning. Since 2015 the preparation of tutors is performed by the Department of pedagogics and psychology of high school, National Pedagogical Dragomanov University according to the master programme licensed by Ministry of Education and Science of Ukraine 011 Educational, pedagogical sciences (Pedagogics of high school. Tutoring). The following disciplines are taught: "Tutoring and tutoring technology", "Organization of students individual work and consultation activity of teacher-tutor", "Grants policy, international projects and programmes of higher education development", "Scientific school and personified experience in world educational dimension" (Demianenko, 2018, p. 49).

The experiment with the participation of the Ministry of Education and Science of Ukraine entitled "Tutoring technology as a means of the individualization principle implementation in education" deserves particular attention. Schools and HEEs from Dnipro, Kyiv, Ternopil and Kharkiv regions 
are involved in the experiment. Tutoring Association of Ukraine is also responsible for the project. It is noted that tutoring should develop such qualities as work in groups, communicability, ability to make decisions, etc. (Experiment of the Ministry of Education and Science of Ukraine, 2015).

In our opinion, the special role in the implementation of the tutors and mentors duties at HEEs belongs to the coordinators of international mobile programs, in particular Erasmus + program coordinators. This is the largest program in Europe today, which provides mobility between teachers, administrators, students and PhD students. Erasmus + coordinators perform roles of tutors (for students) and mentors (for staffs). For example, the coordinator helps to fill out the Learning Agreements for our students, and acts as an intermediary between the teachers of the department, advises on the subjects to be selected in order to obtain the required amount of credits etc. Also, the the coordinator functions include: writing emails to the representatives of the partner university for the proper preparation of the documentation. Concerning staffs, the coordinators help to fill out Staff Mobility Agreement for Teaching and Staff Mobility Agreement for Training. And for those who come to the Ukrainian Universities the coordinators help to solve the problems related with dormitories, finding departmental supervisors for them etc. In both cases the coordinators perform informational and psychological functions which are the most important during the exchang- es between different cultures. The main functions of tutors and mentors which are performed by the Erasmus + programme coordinators are the following: informational, communicative, organizational, educational, psychological (Ivanytska, 2018).

Conclusions and proposals. The conducted research allows us to make the following conclusins:

1. XXI century is marked by significant changes in European Higher Education Area caused by internationalization policy enhancement, academic mobility realization as well as quality assurance improvement at higher educational establishments.

2. Tutoring and mentoring belong to the indicators which directly influence on quality assurance providing, students success and comfortable conditions of study.

3. There is an urgent need for tutoring and mentoring implementation at Higher Educational Establishments of Ukraine in frames of the new Law on Higher Education correspondence and academic mobility increase.

4. During recent years research of tutoring and mentoring by Ukrainian scientists has increased, besides new disciplines on tutoring have been developed and a few experimental projects have been launched. However, there is no systematic approach in tutoring and mentoring implementation as well as a unique model example. Therefore, it is highly important to use the European experience in tutoring and mentoring implementation at HEEs of Ukraine.

\section{References:}

1. Boyko, A. (2010). Tiutorstvo yak zadovolennia osvitnikh potreb osobystosti, krayiny i suspilstva [Tutoring as the accomplishment of educational needs of the individual, country and society]. Teoriya i praktyka navchannia ta vykhovannia, pp. 4-11. (in Ukrainian)

2. Demianenko, N.M. (2018). Posada "pedahoh-tutor": docilnist uprovadzhennia do klasyfikatora profesiy Ukrayiny [Position "Teacher-tutor": expediency of introduction into the professions classifier of Ukraine]. Aktualni problemy vyshchoyi osvity, pp. 47-51. (in Ukrainian)

3. Guidelines for mentoring and supporting students (2005). New South Wales Department of Education and Training, Student Welfare Directorate, p. 16.

4. Ivanytska, O.S. (2018). Erasmus + koordynator yak tutor ta mentor v umovakh zrostannia akademichnoyi mobilnosti u ZVO Ukrayiny [Erasmus + coordinator as tutor and mentor under the conditions of academic mobility increasing at HEEs of Ukraine]. ScienceRise: pedagogical education, № 5(25), pp. 14-18. (in Ukrainian)

5. Nuria Ruiz Morillas, Manel Fandos Garrido (2014). The role of tutoring in higher education: improving the student's academic success and professional goals. Revista Internacional de Organizaciones, pp. 89-100.

6. Pisano, U., Berger, G. (2016). Exploring peer learning to support the implementation of the 2030 Agenda for SD: peer learning as a tool for SD policymaking. European sustainable development network (ESDN), p. 30.

7. Pleschova, G., Simon, E., Quinlan, K., Murphy, J., Roxa, T., Szabo, M., comments of Mieke Clement and Herman Buelens (2012). The professionalization of Academics as Teachers in Higher Education. Standing Commettee for the Social Sciences (SCSS). Science Position Paper, p. 32.

8. Podpliota, S.V. (2017). Titorstvo: istoriya i suchasnist [Tutoring: history and modernity]. Pedahohichni nauky, vyp. LXXV, 2, pp.65-69. (in Ukrainian)

9. Experiment of the Ministry of Education and Science of Ukraine (2015). Retrieved from: https://starylev.com.ua/ news/tyutory-v-ukrayinskyh-navchalnyh-zakladah-novyy-eksperyment-mon. 